\title{
Comparison of the prevalence of Cocoa Swollen shoot virus and the prevalence of Phytophthora sp in Petit-Bondoukou, South-West of Côte d'Ivoire
}

\author{
Franck Zokou Oro $^{1 *}$, Hermann-Desiré Lallie ${ }^{2}$, Nahoua Koné ${ }^{1}$, Juslin \\ Kouadio ${ }^{1}$ and Hortense Atta Diallo ${ }^{3}$
}

\begin{abstract}
${ }^{1}$ Department of Plant biology, Faculty of Biological Sciences, Peleforo GON COULIBALY University. BP 1328 Korhogo ${ }^{2}$ Department of Genetics-Biochemistry, Faculty of Biological Sciences, Peleforo GON COULIBALY University. BP 1328 Korhogo. ${ }^{3}$ Phytopathology Research Unit, Department of Plant and Environmental Protection, Nangui Abrogoua University. 02 BP 801 Abidjan 02 *Corresponding author
\end{abstract}

Received: 01 Nov 2020; Received in revised form: 09 Dec 2020; Accepted: 21 Dec 2020; Available online: 31 Dec 2020 (C)2020 The Author(s). Published by Infogain Publication. This is an open access article under the CC BY license (https://creativecommons.org/licenses/by/4.0/).

\begin{abstract}
Background: Swollen shoot and Black pod disease are two major diseases that cause significant damage in Nawa region. In order to compare the prevalence of these two diseases, a study was conducted in Soubré area in the south-west of Côte d'Ivoire, at the site of Petit-Bondoukou. Methods: The observation system consists of a sentinel site of approximately $10 \mathrm{~km} \mathrm{X} 10 \mathrm{~km}$. Each sentinel site is made up of 16 clusters of $2.5 \mathrm{~km}$ X $2.5 \mathrm{~km}$ containing about 10 plots which constitute the different observation points. In this study, observations were made in 4 plots of the site. The variables that were measured during data collection were the total number of pods on each tree, the total number of pods with black pod disease symptoms and the total number of diseased trees in the swollen shoot outbreaks. The prevalence of each pathogen was deduced from the measured variables and then related using the Bravais-Pearson correlation test. Beforehand, a molecular analysis was carried out to identify the different species of Phytophthora. Results: The results of the molecular analysis showed that the only species identified at this site was Phytophthora palmivora. The descriptive analysis showed that the prevalence of CSSV was higher than that of Black pod disease with 50\% and $32 \%$ respectively. Statistical analysis showed that there is a positive and significant correlation between the prevalence of swollen shoot and black pod disease. Conclusion: This study shows that most of the test trees at the site of Petit-Bondoukou show both Swollen shoot and Black pod disease symptoms and invites growers contribute to reducing the pressure of both diseases by leading regular activities plot maintenance.
\end{abstract}

Keywords-Cocoa trees, CSSV, black pod disease, Prevalence, Côte d'Ivoire.

\section{INTRODUCTON}

The cocoa tree (Theobroma cocoa L.) is a tropical perennial crop of Malvaceae family (Motamayor et al., 2002) formerly classified in the Sterculiaceae family (Metcalfe and Chalk, 1950). The cocoa tree is native to South America and its origin is in the Amazon basin (Motamayor et al., 2002). Cocoa cultivation has been introduced in various West African countries such as Ghana, Cameroon, Nigeria, Togo and Côte d'Ivoire where large plantations have been established (Janny et al., 2003). The extension of cocoa orchards in Côte d'Ivoire is linked to land availability and an attractive and remunerative pricing policy. This is the reason why Côte d'Ivoire has been the world's leading cocoa producer since 1977 (Tano, 2012). This crop is therefore of great importance in the Ivorian economy where it accounts for $40 \%$ of export earnings and contributes up to $15 \%$ of gross domestic product (GDP) (Tano, 2012; Serges, 2014). However, these important socio-economic achievements related to cocoa production in Côte d'Ivoire should not make us lose sight of the many constraints related to diseases, pests and market price fluctuations (Freud et al., 2000). The consequences of these constraints are lower production and 
increased poverty in rural areas. In Côte d'Ivoire, black pod disease and swollen shoot are the two main diseases that pose a major threat to cocoa production (Kouakou et al., 2011).

Black pod disease is caused by Phytophthora spp., with $44 \%$ crop losses (CNRA, 2017). In areas most favourable to black pod disease, losses can reach $80 \%$ of the crop (Koua et al., 2018). In addition, the reappearance of the swollen shoot virus disease in 2003 in the Ivorian orchard (Kébé and N'guessan, 2003) after 60 years, amplifies the threat to cocoa production in Côte d'Ivoire. Swollen shoot is one of the most significant viral diseases in the world (DzahiniObiatey et al., 2010). The Cocoa Swollen shoot Virus (CSSV) responsible for this disease belongs to the genre Badnavirus and is transmitted by mealybugs of the Pseudococcidae family (N'guessan at al., 2016). Swollen shoot disease has not progressed since its discovery in 1946 (Alibert, 1946), and it was only in 2003 that new outbreaks were discovered in the central-western part of the country, notably in Sinfra, Issia and Bouaflé (Kébé and N'guessan, 2003). Today, the swollen shoot species discovered in the new outbreaks are gradually spreading in the Ivorian cocoa plots to the point of posing a real threat to the major cocoaproducing basins such as the Soubré region in the south- west of Côte d'Ivoire. In addition to the damage caused by the swollen shoot disease (Fig.1), there is also the damage caused by black pod disease (Fig.2), thus increasing the risk of a drop in cocoa production. The various known pathogens that commonly cause black pod disease are represented by Phytophthora palmivora and Phytophthora megakarya (Kébé et al., 2009).

In Côte d'Ivoire, Phytophthora megakarya which did not exist in cocoa plots is also beginning to spread significantly (Coulibaly et al., 2013). This species is however the most aggressive (Brasier and Griffin, 1979) unlike P. palmivora which is the least aggressive and most widespread species. In addition, the prevalence of $P$. megakarya is poorly known in Côte d'Ivoire and an interaction between $P$. megakarya and Cocoa Swollen shoot Virus (CSSV) is suspected. This is the reason this study is being conducted.

The objective of this study is to compare the prevalence of swollen shoot virus and that of Phytophthora sp in order to assess the damage caused in plantations by each pathogen. Specifically, the aim is to first characterize the species responsible for black pod disease and then to study the relationship between the prevalence of CSSV and the prevalence of Phytophthora sp.
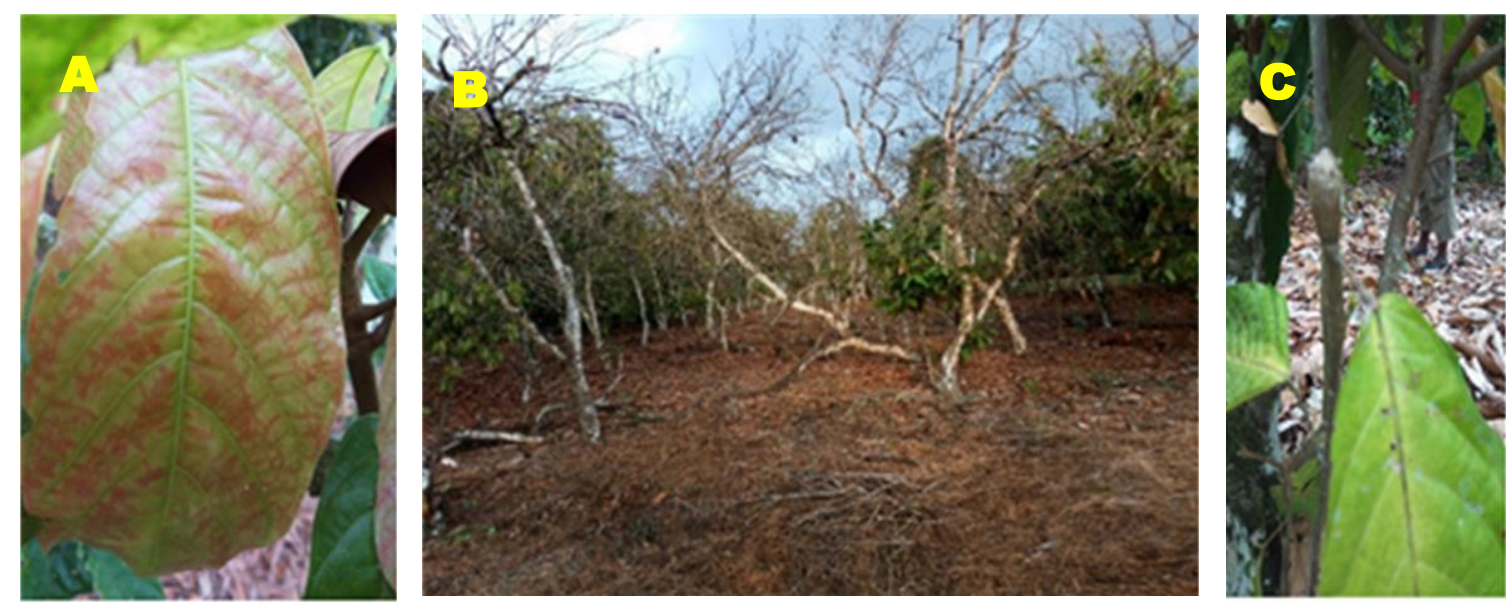

Fig. 1: The different indicators in the plot affected by swollen shoot disease.

$(\boldsymbol{A})$ : redness on young leaves of cocoa trees, $(\boldsymbol{B})$ : Outbreak of swollen shoot disease, $(\boldsymbol{C})$ : Cocoa tree stem swelling $($ Photo taken by Oro Franck) 


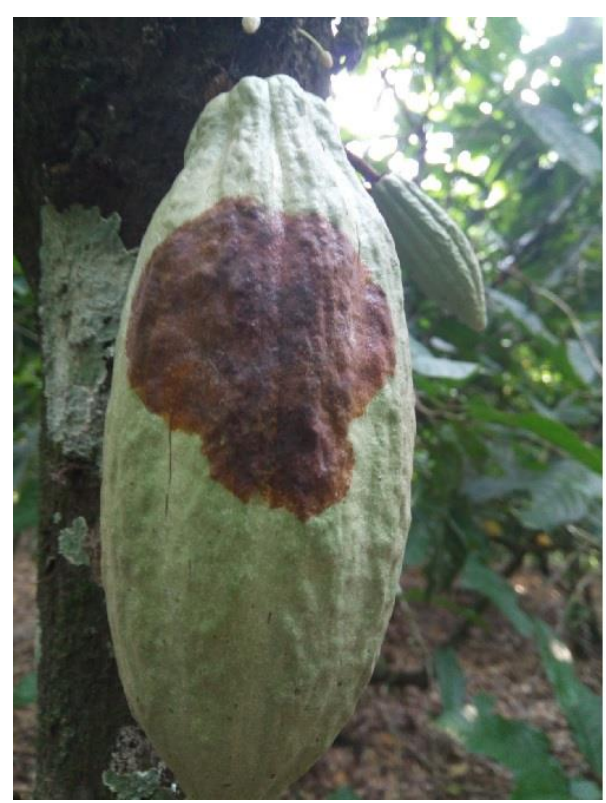

Fig. 2 : Symptoms of black pod disease on immature cocoa pod (Photos taken by Oro Franck)

\section{MATERIALS AND METHODS}

\subsection{Study Area}

This study was carried out in Petit Bondoukou site (Fig.3) located 51 kilometers from Soubré town in Côte d'Ivoire. The Soubré region is currently the main cocoa production area in Côte d'Ivoire. This site is characterized by a humid tropical climate with an average rainfall of 1,485 mm per year, and an average temperature of $25.8^{\circ} \mathrm{C}$ per year. Vegetation and soil are characterized by dense, humid forests and a deep, permeable and well-drained soil that allows for anthropogenic activities related to agriculture (N'go et al., 2012). This vegetation is now giving way to shreds of forest and huge plantations of traditional or industrial perennial crops (Le paysan, 2012).
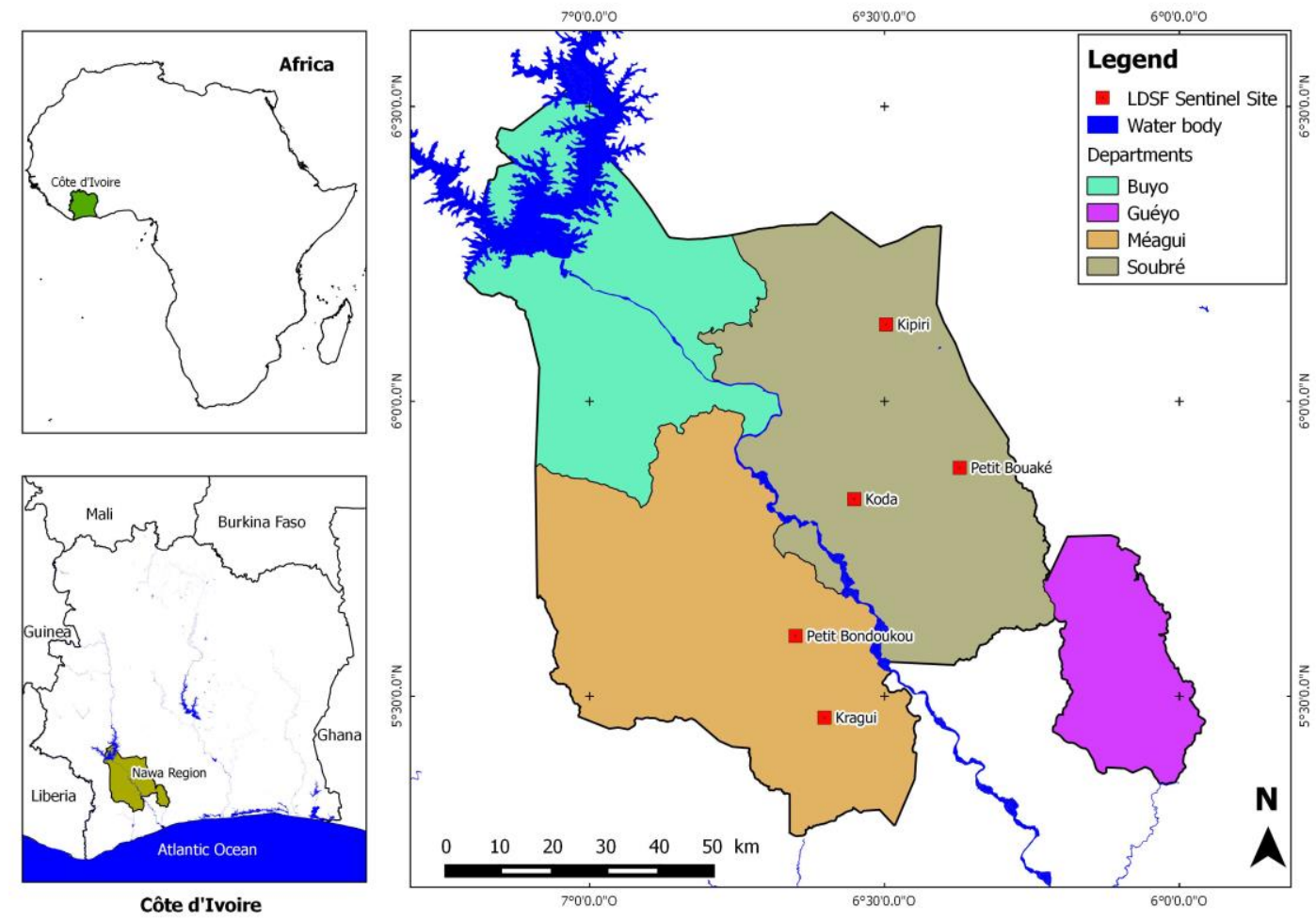

Fig. 3 : Map of the study area showing the site of Petit-Bondoukou (Diby et al., 2014). 


\subsection{Experimental device}

The experimentation took place in peasant cocoa farms based on prospection surveys. These surveys collected data on swollen shoot and Phytophthora sp. These surveys were conducted according to the Land Degradation Surveillance Framework (LDSF) protocol (Diby et al., 2014). The LDSF (Figure 4) is a protocol that was initially developed to monitor soils suitable for agriculture in West Africa. This protocol was adapted in this study for epidemiological investigations of swollen shoot disease and Black pod disease caused by Phytophthora sp (Diby et al., 2014). The LDSF represents a sentinel site of $10 \mathrm{Km} \times 10 \mathrm{Km}$. The site is divided into 16 clusters of $2.5 \mathrm{Km} \times 2.5 \mathrm{Km}$ (Fig.4). Each cluster has 10 observations points, called plots.

\section{$10 \mathrm{~km}$}

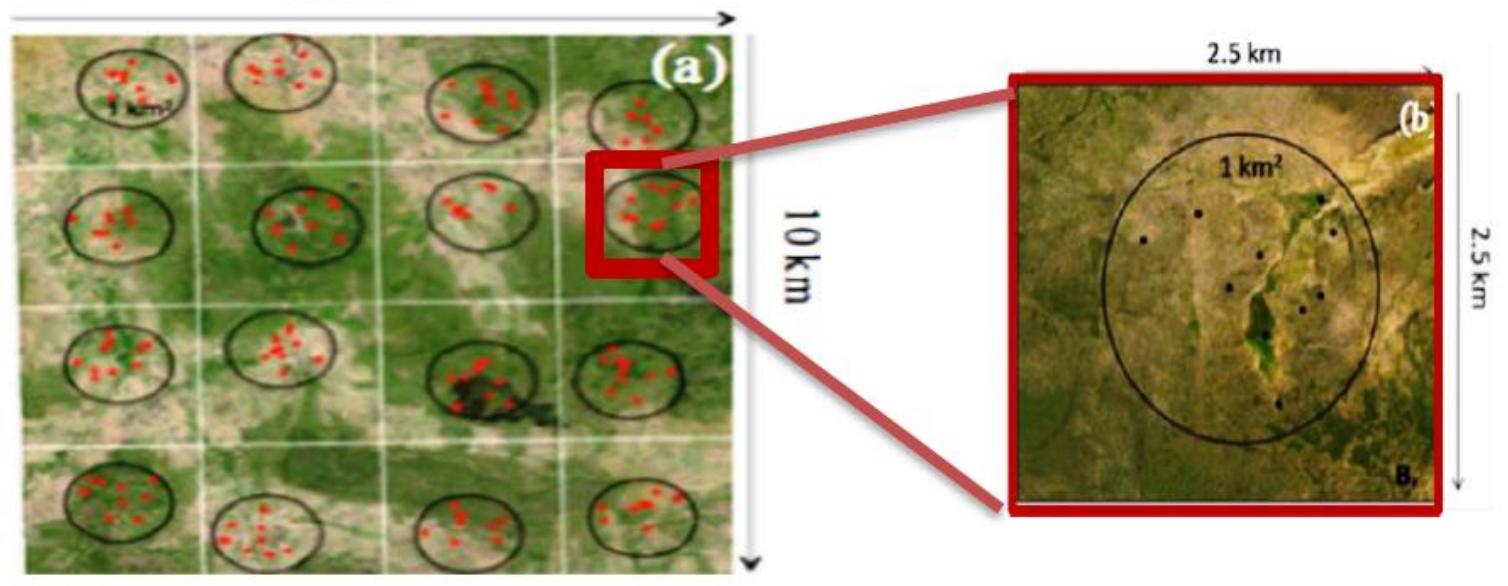

Fig.4 : Land Degradation Surveillance Framework (LDSF) Device (Diby et al., 2014)

\subsection{Observation and data collection}

The data collected are related to swollen shoot and Black pod disease. These data were collected in 4 plots of the Petit-Bondoukou site that were randomly selected. Observations were made on 10 cocoa trees in each plot, corresponding to 40 test trees.

\section{II.3.1 Collection of CSSV data}

The CSSV data collection was carried out at each observation plot, previously identified using the Garmin 64s GPS. Around the plot, an observation area with a radius of $50 \mathrm{~m}$ was delimited. In this observation area, infection outbreak were detected on the basis of several indicators including clearings (Fig.1B), leaf symptoms (Fig.1A) and stem symptoms (Fig.1C). Symptoms on young leaves are represented by redness along the veins and discoloration while stem symptoms are related to swellings on young stems. In each observation area several outbreaks were detected in case of presence of swollen shoot disease. Epidemiological data were collected from each outbreak. It is in these outbreaks that the number of healthy and diseased cocoa trees were counted. The areas of the outbreaks were measured using a Garmin 64 S GPS. A prepared survey form was then filled in to compile the physical data.

\subsubsection{Collection data of Phytophthora sp}

The Phytophthora sp data were collected in the same area as the CSSV data. In contrast to the CSSV data, epidemiological data on black pod disease were collected within a radius of 300 meters around the same test plots (Fig.5). In the case of this study, surveys were only conducted in four (04) plots on the site of Petit-Bondoukou. For each test tree, the total number of pods was counted, as well as the number of pods affected by black pod disease. For the characterization of isolates of Phytophthora species, two samples of pods with symptoms were taken from each test tree. These sampled pods with symptoms were wrapped in newsprint to slow down the development of Phytophthora sp, and then labelled with an identifying code. These pod samples were cross-sectioned along the progressing front of the rotten spot, then a rot explant was taken from the cortex and from an eppendorf tube in the presence of a medium culture favourable to the development of Phytophthora sp. The different tubes were labelled with the codes corresponding to the identifier of sample pods. 


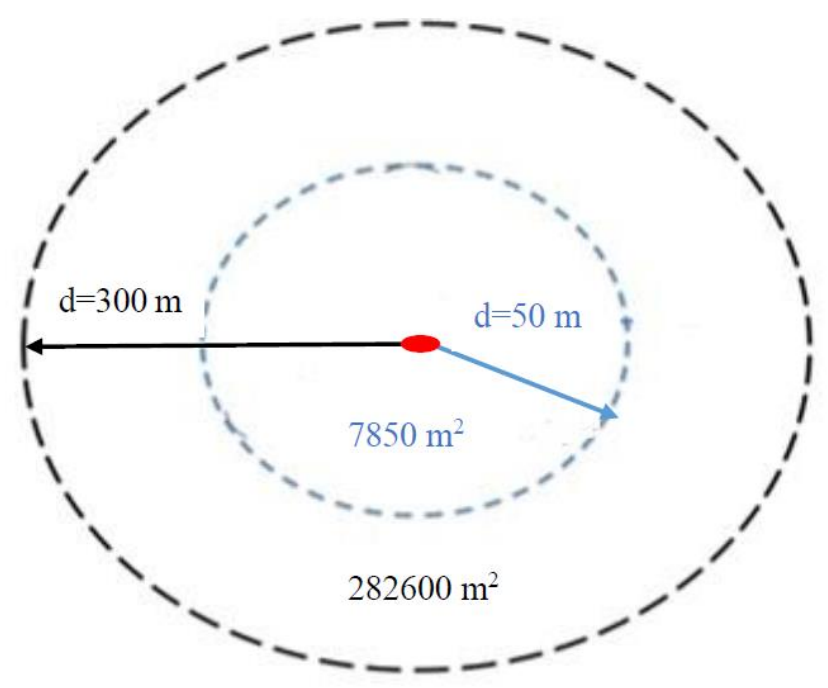

$$
\begin{aligned}
& \text { - - : limite zone d'observation de la pourriture brune } \\
& ---: \text { limite zone d'observation du Swollen shoot }
\end{aligned}
$$

Fig.5 : Observation areas and data collection for CSSV and Phytophthora sp (Diby et al., 2014).

\subsection{Data Analysis}

Data analysis included molecular analysis to identify the different species of Phytophthora sp and statistical analysis to assess the relationship between the prevalence of CSSV and that of black pod disease.

\subsubsection{Molecular analysis}

Molecular analysis of black pod disease data was carried out at the CIRAD Joint Research Unit on Biology and Genetics of Plant-Parasite Interactions in Montpellier, France. This analysis allowed the identification of different Phytophthora species. In the laboratory, the sampled explants were grown in Petri dishes on the "V8" medium culture, which consists of $1 / 10$ of a vegetable juice cocktail, agar at $15 \mathrm{~g} / \mathrm{L}$ and $\mathrm{CaCO} 3$ at $3 \mathrm{~g} / \mathrm{L}$ for 4 days in the dark, at $25^{\circ} \mathrm{C}$. After 4 days, the agar explants containing Phytophthora sp mycelium culture were removed from the fungal growth front with a scalpel and then transplanted into the V8 medium culture under the same conditions described above for 7 days. The resulting mycelium is used for DNA extraction. In case the strains were contaminated with other fungi, several transplants on $\mathrm{H} 2 \mathrm{O}$-Agar culture medium at $15 \mathrm{~g} / \mathrm{L}$ were necessary to purify the strain. After purification, the strain is cultured again on "V8" medium at $25^{\circ} \mathrm{C}$ for 4 days and then 7 days in the dark to obtain a mycelium typical of Phytophthora $s p$. The mycelium obtained after purification is used for DNA extraction. The identification of the different species of Phytophthora was performed by
PCR (Polymerase Chain Reaction) with species-specific ITS primers ( $P$. megakarya and P. palmivora).

2.4.2. Determination of the prevalence of the two plant pathogens

The prevalence of swollen shoot disease is the ratio of the number of diseased cocoa trees counted to the total number of cocoa trees sampled in the observation area. This prevalence is represented by equation 1 . The prevalence of black pod disease is obtained from the ratio of the number of rotten pods to the total number of pods on the selected trees in the plot according to equation 2 . In addition, the prevalence of black pod disease for each species of Phytophthora $s p$ was also determined from the ratio of the number of pods infected by each species to the total number of pods sampled at the site. This prevalence was obtained according to equation 3 .

$$
P \operatorname{CSSV}(\%)=\frac{\text { Number of diseased trees sampled }}{\begin{array}{c}
\text { Total number of trees sampled from } \mathrm{p}] \\
\times 100
\end{array}}
$$

P Phyto $(\%)=\frac{\text { Number of rotten pods }}{\text { Total number of pods on the plot }} \times \mathbf{1 0}$

$$
\begin{aligned}
& \text { P Phyto sp (\%) } \\
& =\frac{\text { Number of pods infected by species }}{\text { Total number of pods sampled on site }} \times 100
\end{aligned}
$$


P CSSV (\%): Prevalence of Swollen shoot disease

P Phyto (\%): Prevalence of black pod disease

P Phyto sp (\%): Prevalence of each Phytophthora species

\subsubsection{Statistical analysis}

Statistical analysis was applied on the prevalence of swollen shoot disease and the prevalence of black pod disease. This analysis first provided a description of these two quantitative variables. Second, it evaluated the relationship between the two variables using the Bravais-Pearson correlation test in SPSS Statistics 20 software.

\section{RESULTS AND DISCUSSION}

\subsection{RESULTS}

\subsubsection{Different species identified}

Molecular analysis revealed a diversity of species of the genre Phytophthora, of which only one was identified as Phytophthora palmivora. The results of molecular analysis showed that the other Phytophthora species are more dominant than Phytophthora palmivora at $93 \%$ compared to $8 \%$ of the pods sampled (Table I). This indicates a prevalence of $23 \%$ for other Phytophthora species compared to nearly $2 \%$ for Phytophthora palmivora (Table II). The species Phytophthora megakarya was not identified at the Petit-Bondoukou site.

3.1.2. Description of prevalences of Swollen shoot disease and black pod disease

The result of the descriptive analysis (Table III) shows that the prevalence of swollen shoot disease at the site of PetitBondoukou is between $0 \%$ and $100 \%$, for an average of $50 \% \pm 32 \%$. The prevalence values of Swollen shoot disease rather scattered around the average show that the prevalence of swollen shoot disease differs strongly from one plot to another at the site of Petit-Bondoukou. In addition, more than half of the plots are affected by swollen shoot disease (Table IV). This shows that there are more diseased trees $(53 \%)$ than healthy trees $(48 \%)$.

Black pod disease also affects this site with a prevalence of between $21 \%$ and $39 \%$. The average prevalence of black pod disease over the whole site is $32 \pm 7 \%$. The prevalence of black pod disease less dispersed around the average explains why the Black pod disease differs little or not at all from one plot to another on the site of Petit-Bondoukou.

Table I: Number of trees infected by the different species of Phytophthora identified at the site of Petit-Bondoukou

\begin{tabular}{ccc}
\hline Phytophthora species & $\begin{array}{c}\text { Number of infected } \\
\text { trees }\end{array}$ & Percentage \\
\hline P. palmivora & 3 & 7,5 \\
P. megakarya & 0 & 0 \\
Other species & 37 & 92,5 \\
Total & 40 & 100 \\
\hline
\end{tabular}

Table II : Prevalence of each species of Phytophthora identified at the site of Petit-Bondoukou

\begin{tabular}{ccc}
\hline & Number of infected pods & Prevalence (\%) \\
\hline Phytophthora megakarya & 0 & $\mathbf{0 , 0 0}$ \\
Phytophthora palmivora & 17 & $\mathbf{1 , 6 2}$ \\
Other species of Phytophthora & 237 & $\mathbf{2 2 , 5 9}$ \\
Total number of infected pods & 254 & $\mathbf{2 4 , 2 1}$ \\
Total sampled pods & 1049 & \\
\hline
\end{tabular}


International Journal of Environment, Agriculture and Biotechnology, 5(6)

Nov-Dec, 2020 / Available: https://ijeab.com/

Table III : Results of the descriptive analysis of the prevalence of Swollen shoot and Black pod disease

\begin{tabular}{|c|c|c|c|c|c|}
\hline & $\mathbf{N}$ & Minimum & Maximum & Average & $\begin{array}{l}\text { Standard } \\
\text { Deviation }\end{array}$ \\
\hline $\begin{array}{l}\text { Prevalence } \\
\text { CSSV (\%) }\end{array}$ & 40 & 00 & 100 & 50 & 35,81 \\
\hline $\begin{array}{l}\text { Prevalence } \\
\text { phyto }(\%)\end{array}$ & 40 & 21,36 & 38,74 & 31,82 & 6,98 \\
\hline
\end{tabular}

Table IV : CSSV status of sampled trees

\begin{tabular}{ccc}
\hline Status of trees & Number & Percentage \\
\hline Diseased & 21 & 52,5 \\
Healthy & 19 & 47,5 \\
Total & 40 & 100 \\
\hline
\end{tabular}

3.1.3. Relationship between the prevalence of swollen shoot and black pod disease

The result of the Bravais-Pearson correlation test (Table V) showed that there is a positive and significant correlation $(\mathrm{r}=0.814 ; \mathrm{p}=0.000)$ between the prevalence of CSSV and the prevalence of Phytophthora sp. This shows that the development of one of these diseases favours the development of the other.

Table V: Result of the correlation test between the prevalence of CSSV and the prevalence of Phytophthora sp.

\begin{tabular}{llcc}
\hline Correlation & & $\begin{array}{c}\text { Prevalence } \\
\text { CSSV (\%) }\end{array}$ & $\begin{array}{c}\text { Prevalence } \\
\text { Phytophthora }\end{array}$ \\
\hline & $\begin{array}{l}\text { Correlation of } \\
\text { Pearson }\end{array}$ & 1 & $\mathbf{0 , 8 1 4}{ }^{* *}$ \\
Prevalence CSSV (\%) & Sig. (bilateral) & & $\mathbf{0 , 0 0 0}$ \\
& N & 40 & 40 \\
\hline
\end{tabular}

** The correlation is significant at the 0.01 level (bilateral).

\subsection{DISCUSSION}

The result of the descriptive analysis showed that swollen shoot disease is very present in Petit-Bondoukou with a proportion of $50 \%$. This result is in line with the results of the work of Diby et al (2014) which showed that the PetitBondoukou site is a sentinel site with a high presence of swollen shoot disease with a prevalence rate of $63.4 \%$.The results of molecular analysis also showed that the Phytophthora species identified at the study site are Phytophthora palmivora and other Phytophthora species that were not the subject of this study. The species Phytophthora megakarya has not been identified at the site of Petit-Bondoukou. This result is in agreement with the work of Babacauh (1980) which showed that the only Phytophthora species responsible for black pod disease were Phytophthora palmivora and Phytophthora citrophthora. From the above, damage related to other species not identified in this study could be linked to Phytophthora citrophthora. Indeed, the absence of Phytophthora megakarya at the site of Petit-Bondoukou could be explained by the sampling period which took place towards the end of August. At this period, opportunistic pathogens take over the development of Phytophthora palmivora and P. megakarya (Kébé et al., 2001; Koné, 1999). Statistical analysis has shown that the presence of CSSV is significantly related to the presence of black pod disease, i.e. the presence of one of these diseases favours the occurrence and/or development of the other. This result shows that both diseases are increasing strongly at the site of Petit-Bondoukou. This means that most of the test trees show both signs of swollen shoot and black pod disease. 
Indeed, observations were made on early-infected trees still showing a high level of leaf cover. This high rate of leaf cover could be at the origin of a humid microclimate (Yao et al., 2014; Koua et al., 2018) which could favour the dispersal of the Phytophthora pathogen, as well as the development of scale insects that are vectors of swollen shoot disease. This is in line with the studies carried out by Bigger (1972) and Nguyen-ban (1984) which reveal that these climatic conditions favour the outbreak of mealybugs in cocoa trees. These arguments are supported by Brasier and Hansen (1992) who showed that rainfall favours the establishment and development of phycomycetes diseases such as black pod disease due to Phytophthora $s p$. As for mealy bugs of the family Pseudococcidae, the vector species of the swollen shoot virus, have a development cycle which varies according to climatic conditions including temperature, humidity and according to the host plant (Kenza, 2017). According to Goldasteh et al (2009) the optimal temperature for development of scales to adulthood is between $15^{\circ}$ and $32^{\circ} \mathrm{C}$. These development conditions correspond to the climatic parameters of the Soubré region where swollen shoot disease occurs.

\section{CONCLUSION}

Swollen shoot and black pod diseases are two major cocoa diseases that cause significant losses in the region of Soubré. At the end of this study, it appears that the site of Petit-Bondoukou is a sentinel site with a high presence of swollen shoot disease. Molecular analysis showed that the only species identified on this site is Phytophthora palmivora although there is a strong propensity for other unidentified species responsible for black pod disease. This study also showed that there is a strong positive correlation between the prevalence of swollen shoot and the prevalence of Black pod disease. This shows that most of the test trees at the site of Petit-Bondoukou show both Swollen shoot and Black pod disease symptoms. To limit the spread of these two diseases, firstly, regular plot maintenance should be carried out by regular weeding and regular pruning of the plots to adjust the light and thus break the cycle of Phytophthora sp. Secondly, to limit the spread of Swollen shoot, growers should be made aware of the recognition of symptoms so that they can take action by destroying the first trees bearing the symptoms of the disease. This combined action could greatly contribute to reducing the pressure of both diseases.

\section{CONFLICT OF INTEREST}

The authors declare that they have no conflict of interest.

\section{ACKNOWLEDGMENTS}

Our thanks go to the firm SAG SARL for facilitating the implementation of the study, the collection of data and the production of the final report of the study.

\section{REFERENCES}

[1] Alibert H. 1946. Note préliminaire sur une nouvelle maladie du cacaoyer le «Swollen shoot ». Agronomie Tropicale, Paris, V.1, pp. $34-43$.

[2] Babacauh K.D. 1980. Structure et dynamique des populations de Phytophthora sp. Parasite du cacaoyer (Theobroma cacao L.). Thèse de Doctorat d'Etat. Université de Paris -Sud, centre d'Orsay, 153 p.'

[3] Bigger, M. 1972. Recent work of the mealybug vectors of cocoa Swollen shoot disease. In: Ghana. PANS, 19: pp. 6170.

[4] Brasier, C.M. and Hansen E.M. 1992. Evolutionary Biology of Phytophthora, Part. II: Phylogeny, speciation, and population structure. Annu. Rev. Phytopathology. 30:173200.

[5] Brasier C. M. \& Griffin, M. J. 1979. Taxonomy of Phytophthora palmivora on Cocoa. Transactions of the British Mycological Society, 72, 111-143.

[6] Centre National de Recherche Agronomique (CNRA). 2017. Bien lutter contre la pourriture brune des cabosses du cacaoyer en Côte d'Ivoire. $4 \mathrm{p}$

[7] Diby L., Guillaume K., Marie-Paule N., Eric Y., Franck O., Ermias A., Emmanuel K., Christophe K., Richard C., Keith Shepherd. 2014. Cocoa Land Health Surveillance: An evidence-based approach to sustainable management of cocoa landscapes in the Nawa region, South-West Côte d'Ivoire. Working Paper 193. Abidjan, World Agroforestry Centre.

[8] Coulibaly K., Kébé B., Koffi K., Mpika J., Koné D. 2013. Caractérisation des isolats de Phytophthora spp du verger cacaoyer de Cote d'Ivoire. Journal of Applied Biosciences 70:5567- 5579

[9] Dzahini-Obiatey H., Owusu D. et Amoah F. M. 2010. Over seventy years of a viral disease of cocoa in Ghana: From researchers' perspective African Journal of Agricultural Research Vol. 5 (7), pp. 476-485.

[10] Freud E.H., Petithuguenin P. et Richard, J. 2000. Les champs de cacao: un défi de compétitivité Afrique Asie. Editions Karthala et CIRAD, Paris, 207 p.

[11] Goldasteh S. et al. 2009. Effect of temperatureon life history and population growth parameters of Planococcus citri (Homoptera, Pseudococcidae) on coleus [Solenostemonscutellarioides (L.) codd.] - Arch. Biol. Sci., Belgrade, 61 (2), p.

[12] Janny G. M. Vos B. J., Ritchie., Julie F. 2003. Guide pour la formation des facilitateurs. CABI Biosciences, 114p.

[13] Kebe B., N'guessan F.K., Keli J.Z., and Bekon A. K. 2001, Cocoa IPM research and implementation in Côte d'Ivoire. In proceedings of the west African Regional Cocoa IPM Workshop. Benin November 2001. 46 - 51 
[14] Kébé, B.I. et N'guessan, K. F. 2003. Rapport de la mission de prospection du Swollen shoot. 11 - 13 Septembre 2003. C.N.R.A - Divo, 7 p.

[15] Kébé B. I., Joseph M., Kouamé F. N., Prakash K. H., Gary S. S., \& AKE S. 2009. Isolement et identification de microorganismes indigènes de cacaoyères en Côte d'Ivoire et mise en évidence de leurs effets antagonistes vis-à vis de Phytophthora palmivora, agent de la pourriture brune des cabosses. Sciences \& Nature Vol.6 Nº1: 71 - 82 (2009).

[16] Kenza D. 2017. Stratégie de lutte biologique contre la cochenilles farrineuses sur Choisya Ternata (Oranger du Mexique). Mémoire, mention Biologie et Technologie du Végétal, Université Angers, France, 57 p

[17] KoneY.R.1999. Étude de la structure actuelle des populations de Phytophthora spp. Agent de la pourriture brune des cabosses du cacaoyer (Theobroma cacao L.) en Côte d'Ivoire. Mémoire de Diplôme d'Agronomie Approfondie option défense des cultures ESA Yamoussoukro 111p.

[18] Koua S. H., Coulibaly N. A. M-D., Alloue boraud W. A. M. 2018. Caractérisation vergers et des maladies de cacao de la Côte d'Ivoire: cas des départements d'Abengourou, Divo et Soubré. Journal of Animal \&Plant Sciences, 2018. Vol.35, Issue 3: 5706-5714.

[19] Kouakou K.2014. Diversité moléculaire du CSSV (Cocoa Swollen shoot virus) et épidémiologie de la maladie du Swollen shoot du cacaoyer (Theobroma cacao 1.) en Côte d'Ivoire. Thèse de Doctorat de l'Université Felix Houphouët Boigny, 135p.

[20] Kouakou K., Kébé BI., Kouassi N., Aké S., Cilas C., Muller E. 2012. Geographical distribution of Cacao Swollen shoot virus molecular variability in Côte d'Ivoire. Plant Dis. 96: 1445-1450.

[21] Kouakou K, Kebe BI, Kouassi N, Anno AP, Ake S, Muller E. 2011. Impact de la maladie virale du Swollen shoot du cacaoyer sur la production de cacao en milieu paysan à Bazré (Côte d'Ivoire). Journal of Applied Bioscience 2011; 43: 2947-2957.

[22] Metcalfe et Chalk. 1950. Anatomie des dicotyledons. Journal of pharmacy and pharmacology, 1950. Volume 1 et 2, 862-863 pp.

[23] Motamayor, J C. Risterucci, A M., Lopez, P A. Ortiz, C, F., Moreno, A., Lanaud, C. 2002. Cacao domestication I: the origin of the cacao cultivated by the Mayas. Heredity 89: 308-3.

[24] N'guessan A.H., N'guessan K.M., Kouamé N.N., Kouassi K.P., N'guessan W.P. 2016. Distribution géographique et importance des foreurs de tige dans le verger de cacaoyers de Côte d'Ivoire. Journal of Animals and Plant Sciences. Vol. 27 (3): 4282-4292.

[25] N'Guettia A.M.C., 2015. Efficacité de doses de deux formulations de Movento (Ketoenoles) contre les cochenilles farineuses, vectrices du virus Swollen shoot du cacaoyer dans la localité de Soubré (Sud-ouest de la Cote d'Ivoire). Mémoire de Master de l'Université Felix Houphouët Boigny, Abidjan, Côte d'Ivoire, 58 p.
[26] Nguyen-Ban, J. 1984. "Variations d'abondance des pseudococcines vectrices de la maladie du Swollen-shoot au Togo. Café Cacao Thé 28 ( $\left.{ }^{\circ} 2\right)$ : 103-110 pp.

[27] Serges T., 2014. Cote d'Ivoire: 1,74 million de tonnes de cacao récoltées en 2013-2014, record historique, Economie AFP, 6p.

[28] Tano M. A., 2012. Crise cacaoyère et stratégies des producteurs de la sous-préfecture de Meadji au Sud- Ouest Ivoirien. Thèse de doctorat de l'Université de Toulouse, France, 242p.

[29] Yao KT, Oga M, Kouadio KE, Fouché O, Ferriere G, Pernelle C 2014. Rôle hydrogéologique des linéaments structuraux en milieu cristallin et cristallophyllien : cas du bassin versant du Sassandra, Sud-Ouest de la Côte d'Ivoire. Afrique Science 10 (4): 78-92.

[30] P.K. N'go, F.Z. Azzaoui, A.O.T. Ahami, Y. Aboussaleh, A. Lachheb, A. Hamrani, 2012. Déterminants socioéconomiques, environnementaux et nutritionnels de l'échec scolaire: Cas des enfants résidant en zone cacaoyère de Soubré (Côte d'Ivoire). Antropo, 28 (2012) 63-70.

[31] Le paysan. 2012. Le cacao de A à Z, le paysan n ${ }^{\circ} 003$ (2012) $68 \mathrm{p}$. 